\title{
Making Connection: Integrating Gamelan Music into Social Studies Classroom
}

\author{
Yayuk Mardiati ${ }^{1}$, Wasino ${ }^{2}$, Dhanang Respati Puguh ${ }^{3}$, Eko Handoyo ${ }^{4}$ \\ ${ }^{1}$ Postgraduate, Universitas Negeri Semarang \\ ${ }^{2}$ Faculty of Social Science, Universitas Negeri Semarang \\ ${ }^{3}$ Faculty of Humanities, Diponegoro University \\ ${ }^{4}$ Faculty of Social Science, Universitas Negeri Semarang \\ Corresponding Author: Yayuk Mardiati
}

\begin{abstract}
With the publication of the United Nations, Educational, Scientific and Cultural Organization (UNESCO) on report of the Asian Regional Symposia on Arts Education nearly one and decades ago, scholars and educators have urged Asian teachers, including Indonesia to incorporate arts and culture into curriculum to improve the quality of education, yet efforts connecting arts, especially gamelan music into social studies is lacking. Built upon the previous research on integrated curriculum which aligned with National Education Standard Board (Indonesian: Badan Standar Nasional Pendidikan or BSNP), on both process and content standards this article aimed to offer a rationale for incorporating Javanese gamelan music potential into social studies classroom and propose a framework for planning. Social studies classroom components included assigned readings on Indonesian national history, especially in the Hindu-Buddhist eras in small group discussion. With this approach and its lesson it is presumed that social studies and gamelan teachers benefit of integrating gamelan music into social studies.
\end{abstract}

Keywords: Javanese gamelan, integration, framework, social studies

\section{INTRODUCTION}

There are growing body of research that support the integration of arts as an instructional approach of teaching that helps middle school students construct an understanding through music form and content area in social studies (Werner \& Freeman, 2001; Isenberg \& Jalongo, 2010; Zarillo 2014; and Silverstein \& Layne, 2010). In this sense, to integrate music into social studies requires both music objective and content area in social studies objective, both of which are treated equally (Silverstein \& Layne, 2010; Burstein \& Knotts, 2010; Zhou \& Brown, 2018). In other words, to make music-integrated one, it is necessary to include concepts from social science discipline, including cultural anthropology to analyze both musical structure and meaning from which to draw. Social studies educators and researchers contend that students' employment of various cultural artifacts, such as architectural designs, relics, and musical instruments allow students to reason with democratic values (VanSledright, 2002; Taylor, et al., 2014). This notion is in line with the publication of the United Nations, Educational, Scientific and Cultural Organization (UNESCO) report of the Asian Regional Symposia on Arts Education nearly one and decades ago which scholars and educators have urges Asian teachers, including Indonesia to incorporate arts and culture into curriculum to improve the quality of education. However, social studies junior high school teachers in Indonesia have not taken seriously to integrate gamelan music potentials into social studies classroom. In middle schools in Indonesia, gamelan music 
was and is taught as a separate art subject to master the content, processes, and technical aspects of gamelan playing. In spite of the employment of gamelan music into Indonesian schools and its unique democratic elements, there are limited researches investigating gamelan music potential to enhance young people's democratic values. According to Silverstein \& Layne (2010) studies on connecting music includes exploring the elements of music, creating through improvisation, conducting, composing, exploring musical styles, writing song lyrics, exploring musical phrasing, playing instruments, singing, listening, critiquing music, and exploring music as a reflection of a culture. In addition, in order for music and social studies to be integrated, teachers are able to choose social studies area or content, such as world cultures and historical time periods and events or on concern/need, such as multicultural education, multiple intelligences, students with special needs, learners of English, social skills (cooperation, collaboration, and communication), and habits of mind. According to Zhou \& Brown (2018) studies on Western musical forms include such elements as fixed pitch (melody and harmony), rhythm (meter, tempo, and articulation), dynamic (soft-loud), and the qualities of timbre and texture (the density of thickness or thinness of layers of sounds). Unlike Western music which is played according to fixed pitch, many ethnographic studies emphasized description and analysis of technical aspects of Javanese gamelan structure which related to Javanese culture. This aligned with Alan Merriam's conceptualization of music as culture (Merriam, 1969). He asserted that music has been a product of human behavior (motor and social behavior). Therefore, the study of music provides knowledge of the culture of which it is a part (Merriam, 1969). Similarly, Hood (1980) and Bakan (2011) pointed out that to know and understand a society, one should know its music. These assertions imply that to understand gamelan music, one should know the general nature of Javanese culture and appreciate how music reflects its structure and values. Therefore, it is critical to include social science concepts, especially cultural anthropology by incorporating Javanese gamelan music into social studies.

\section{Defining Arts-Integrated Connections}

Silverstein \& Layne (2010) define arts-integrated connection as identifying specific art focus (visual or performing arts) and connecting it to a specific curriculum area (social studies, science, math etc.) or a specific concern/need - an issue educators consider crucial (such as: character education, multiculturalism, habits of mind, etc.). This definition focuses on goals of arts-integrated connection which is mutually reinforcing connection. In other words, Silverstein \& Layne (2010) emphasize on engaging students in creative process (skill or concepts) in art form, including music which connects social studies is equally important to meet evolving objectives in both. In Indonesia context, the definition may apply on how learning gamelan music reinforces learning in the area of concern of democratic values. Conversely, learning in the area of concern of democratic values extends learning in gamelan music. Burstein \& Knotts (2010) and Zhou \& Brown (2018) emphasized objectives of arts-integration in social studies which has co-equal status, meaning that even though the primary objectives of teaching focuses on social studies, the arts, including music must also have equal importance to validate its inclusion. Similarly, Berke (2000) defines the term integration as combining two equal groups into a unified whole. Further, some scholars argue that integrated curriculum is inherently concerned with big ideas or shared concepts (Parsons, 2004). Beane (1997) notes that the integration of arts in different subject extends the importance of the connections for larger issues in the curriculum, such as inquiry, democratic processes, and problem solving. This notion of shared concept supports the arts 
integration, especially gamelan music in social studies that can address larger issues or inquiry of democratic values in the curriculum. The research results on how social studies and gamelan teachers perceived the teaching of gamelan have been published in a separate article (Mardiati et al., 2019).

\section{Theories and Framework related to Arts- Integrated Connections Constructivist Learning Theory}

The nature of arts-integrated connection lends itself to constructivism, meaning that constructivist learning is described similar to art learning (Scott, 2011). Constructivist learning was built on the work of psychologist Jean Piaget, who believed that children build their own knowledge through play and their experiences. Piaget's theory of cognitive development suggests that as children grow their intelligence changes (Kurt, 2021). These cognitive structures change through the processes of assimilation and accommodation to create equilibrium (Kurt, 2021). Vygotsky extended constructivism's view who posits that knowledge is produced culturally through collaborations with environment and other people (Kurt, 2021). In this sense, constructivist learning is based participatory on the construction of both creation of individual and social knowledge. Such constructivist ways of knowing can also be researched and applied related to arts-integrated connections.

\section{Arts-Integrated Connections}
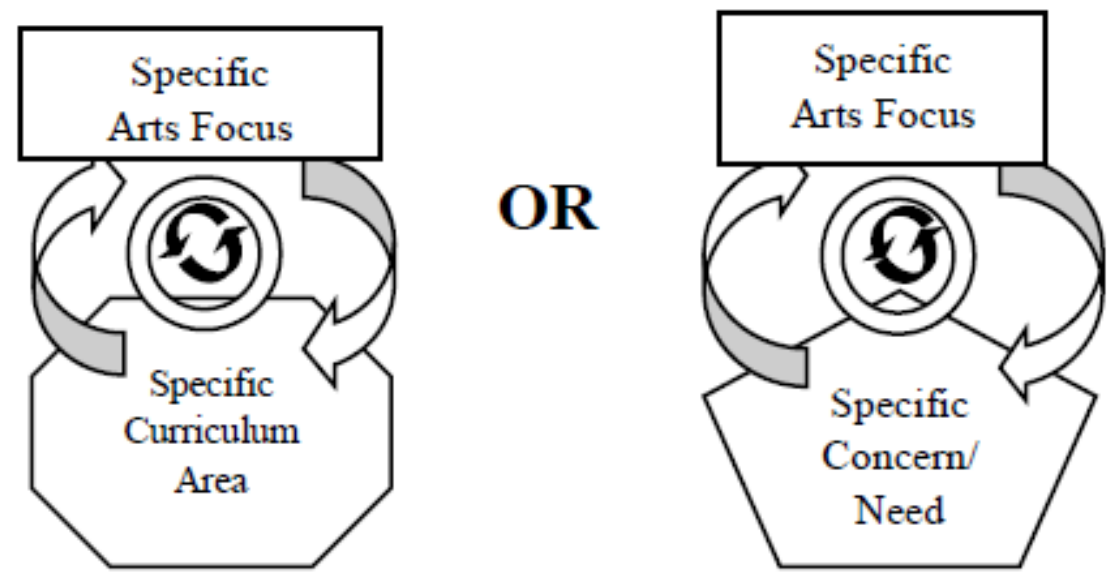

Source: Silverstein \& Layne (2010)

Figure 1. Arts-Integrated Connections Framework

In this arts-integrated connections framework, Silverstein \& Layne (2010) focused on visual or performing arts and connect it to another specific subject, such as science, mathematics, social studies, language arts or specific area of need or concern, such as character education, habits of mind, equality, multicultural. Some scholars referred this framework as co-equal approach to integration, where the arts and core academic objectives have the same level of importance and therefore, should be incorporated equally (Bresler, 1995; Ozgul, 2016; Burstein \& Knotts, 2011). In order to create an integrated use of visual arts while teaching social studies content, Burstein \& Knotts (2010) offered five steps for planning; (1) choosing a social studies content standard that will be reflected in the unit based on a theme aligned with the US the national curriculum standards for social studies (NCSS), (2) choosing a visual art content standard that complements the concepts and skills the teacher wants to teach in social studies, (3) creating learning objectives in both social studies and visual arts for the unit of study, (4) teaching academic content vocabulary in both subjects areas, and (5) creating a performance-based assessment with clear 
criteria in the social studies and the visual arts. Considering the importance of the coequal integration of both the social studies and arts curricula, incorporating gamelan music with social studies in Indonesia middle schools is critical to help students understand social studies content while being immersed in gamelan playing. Building upon the work of Silverstein \& Layne (2010) and Burstein \& Knotts' framework (2010) this article proposes framework for planning on gamelan musicsocial studies connections in helping students explore democratic values. In order to create integrated use of gamelan music while teaching social studies content it is necessary to align with National Education Standard Board (Indonesian: Badan Standar Nasional Pendidikan or BSNP), on both process and content standards.

The Proposed Framework for Gamelan music-social studies connections

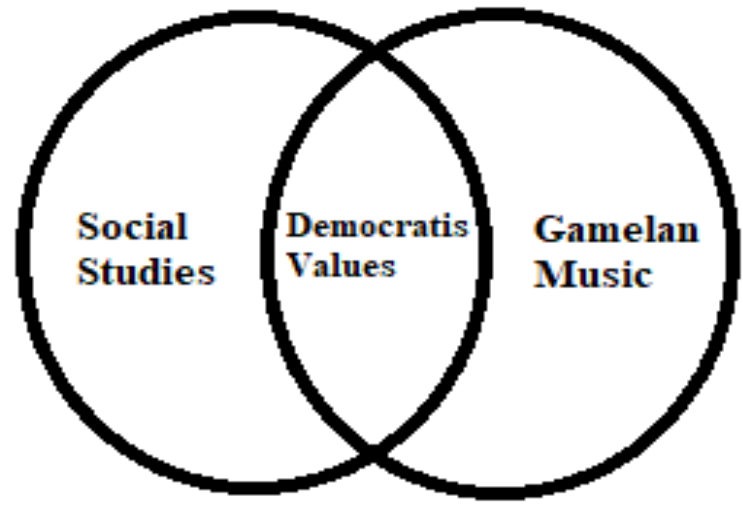

Figure 2.Gamelan music-social studies connections framework

In this gamelan music-integrated connection framework, students simultaneously enhance historical thinking while having immersed in gamelan playing, to co-create to make music, understand the balance/peaceful, cooperation, collaborative leadership concepts, and the importance of individual player in gamelan playing, all of which pertain democratic values.

\section{The proposed lesson plan for integrating gamelan music into social studies classroom}

Subject: Social studies/gamelan
Integrated Strand: Hindu and Buddhist Kingdoms in Java and gamelan

Grade levels/SMT: 7-8/2

Class Period Required: A three-week 40 minute periods

\section{Purpose, Background, and Context for Unit:}

Students need to understand the communicative power of music, appreciate the importance of its aesthetic touch in life, and most importantly understand that music might be used as a means of expressing democratic values. This instructional unit is designed for middle school students, especially social studies classroom in Indonesia.

Students understand that gamelan music has existed in Java, but they try to identify its background, including its functions and development. In this threeweek unit, students will explore democratic and historical concepts, using anthropological perspectives, from relevant sources that encompass the cultural elements of the gamelan instruments in Java. The Students will obtain a perspective of the art of gamelan music as a reflection of Javanese cultural values that foster democratic values and as a powerful tool to understand the past.

\section{Objectives and Performance for Unit:}

Students will:

- Explain and apply ideas and modes of inquiry drawn from cultural anthropology that examines Javanese gamelan music related to systems of beliefs, values, and traditions (Indonesian Middle School Curriculum, 2013)

- Explain how gamelan music contributes to the cultural history of Indonesia (Indonesian Middle School Curriculum, 2013)

- Understand particular aspects of culture as an integrated whole which explain the functions and interaction of literature and the arts (NCSS Standard, 2010, p.68) 
- Explain and apply ideas and modes of inquiry drawn from history which examine the art of gamelan music and its relation to Javanese history (NCSS Standard, 2010, p.68, Indonesian Middle School Curriculum, 2013)

- Demonstrate gamelan instruments to exercise their ability to express the sensitivity of art and to express democratic values and practice.

Lesson 1: The Javanese Hindu and Buddhist Kingdoms and Gamelan

Class Period Required: Two 40 minute periods

Goal: To help students understand the picture of religious architecture of Borobudur and Prambanan temples which represent the combination of Indian influences and Javanese civilization.

\section{Objectives:}

\section{Students will:}

- Identify the monumental religious architecture of Borobudur and Prambanan temples in Magelang, Central Java, Indonesia.

- Explore how aspects of Hindu and Buddhist beliefs and practices were combined with Javanese culture and analyze the impact of these cultures at present.

- Explain the rise of the Javanese kingdoms of Mataram and evaluate its achievement in literature and art, including gamelan music.

- Explain the functions of gamelan music in religious, social, and theatrical context in the past and present.

\section{Materials:}

Map of Central Java

Social Studies/History book

Pictures of Borobudur and Prambanan temples from Kanisius, Jakarta

Pictures depicting musical instruments on temple relief

Hand-out of Gamelan

\section{Procedures:}

Day 1:

Procedure 1: 5 minutes

As an introductory lesson, show students the map of Central Java. Ask if anyone can show the location of Magelang residency.

\section{Procedure 2: 15 minutes}

Using Coopertative Learning Model: Think-Pair-Share, break the class into groups of four, naming each TEAM. So they will have TEAM-1, TEAM-2, TEAM3, TEAM-4. Show students on LCD Projector pictures of Borobudur and Prambanan temples and a picture depicting musical instruments on temple relief. Have students observe the pictures. Have the TEAMs make a list of ideas in response to the questions "What do you see in the pictures?" and "What might be inferred from the pictures?" Assign a recorder on each TEAM to record the students' ideas. Each member of the TEAM should contribute at least one idea. Each member of the TEAM is encouraged to keep a journal that will be collected at the end of the lesson.

\section{Procedure 3: 10 minutes}

In a whole class discussion, have the recorders from each group or TEAM write their group's ideas on the board. Teacher compares and contrasts the answers of one group with the others to find out the similarities and the differences of their answers.

\section{Procedure 4: 10 minutes}

Have students write a journal entry on what they have learned from the lesson.

\section{Day 2:}

\section{Procedure 1: 10 minutes}

Have students read history text-book pages 25-29 on "Development of the Javanese Hindu and Buddhist Kingdoms" and brainstorm ideas based on the questions:

- What contributes to the rise of the Javanese Hindu and Buddhist kingdoms?

- Explain their achievements 


\section{Procedure 2: 10 minutes}

Have students make a mind-map based on the ideas of the rise of the Javanese Hindu and Buddhist kingdoms and their achievements

\section{Procedure 3: 20 minutes}

Help students' curiosity by asking questions:

- Explain the different between the characteristics of the architecture of Prambanan temple and Borobudur temple; what are they made of, how were they built, what materials were required to build the temples, and what they were and are for?

- Explore how aspects of Indian influence and Javanese culture were expressed in the depiction on the temple relief.

Have each member contribute to least one answer and tell students to obtain any resources that support the answers. Have the recorder write down the answers of the team.

\section{Lesson 2: The Features of Javanese} Gamelan

Class Period Required: Two 40 minute periods

Goal: To help students understand that Gamelan can foster democratic values.

Objectives:

Students will:

- Identify the orchestration of Gamelan music

- Listen attentively to the Gamelan music

- Interpret the structure of Gamelan music using visual representation

- Interpret the sounding of the Gamelan music using audio representation

- Explore the democratic concepts in Gamelan music

\section{Materials:}

Picture of gamelan instruments

Compact Disk of gamelan music

Hand - out of an article on Javanese gamelan music

\section{Procedures:}

Day 1:

\section{Procedure 1: 15 minutes}

Show students on LCD Projector a picture of gamelan instruments. In groups of four have two members of each group identify the orchestration of gamelan music.

Assign a recorder of each group to make a list of the group's ideas. It is advisable that each member in each group contributes one idea.

Procedure 2: 10 minutes

Have students remain in their groups. Instruct the recorder of each group to write on the board. Then compare and contrast each group's ideas of the structure of the gamelan instruments.

\section{Procedure 3: 10 minutes}

Have students write a journal entry based on procedure 1 and 2

\section{Procedure 4: 5 minutes}

Collect students' work to assess the success of the activity.

\section{Evaluation}

Teacher monitors students working in cooperative groups.

\section{Day 2:}

\section{Procedure 5: 30 minutes}

Have students listen attentively to the Gamelan music. Using the cooperative learning: Think - Pair- Share, have students write down their ideas (think) in response to the questions:

- What instruments did they hear?

- How the musicians play the instruments?

- Who the conductor is?

- How they feel about the music?

Have students discuss those ideas with a neighbor (pair), and have students share those ideas with the class (share). During the process, teacher guides students toward the understanding of balance/ peaceful, cooperation and leadership concepts, and the importance of individual/s found in gamelan music. 


\section{Procedure 6: 10 minutes}

Have students write a brief essay based on procedure 5 .

Lesson 3: The Implementation of the playing of the gamelan instruments as expressions of the Javanese values and of democratic practice (metaphorically: democratic actions can be analogous to the playing of the gamelan instruments)

\section{Class Time Period: Two 40 periods}

Goal: To make students aware of the playing gamelan which is as an expression of Javanese/Indonesian culture is also an expression of democratic practice.

\section{Objectives:}

\section{Students will:}

- make choices of the instruments they play

- be responsible to work in cooperation

- be free to create any improvisation, if necessary.

- be flexible and spontaneous to the playing of any instruments.

\section{Materials:}

- A set of Gamelan instruments

- The hand-out of the notation of a song "Ibu Pertiwi", or " Mother Earth"

\section{Procedures}

Day 1:

\section{Procedure 1: 10 minutes}

Distribute the hand-out of the song "Ibu Pertiwi" or "Mother Earth"

Using an apprenticeship approach, students are told to really pay attention to the playing to the instruments using cipher notation. Provide students choices of the instruments they play. Students who play the principal melody of the balungan or saron family are told to use the dumping technique with left hand thumb and index finger as succeeding is struck to prevent the blurring sound quality. Students who play the colotomic parts of the gong family are told to match as closely as possible to the balungan. Students who choose to play the embellishing instruments are told to create any improvisation. Assign 4 male choruses Javanese gerongan who also do handclapping - Javanese keplok which produce wonderful interlocking patterns. Assign 2 female singers - Javanese pesindhen.

\section{Procedure 2: 5 minutes}

Have students hold the wooden mallet - Javanese panakol used for the playing of percussion instruments. As a warming up, have individual student tune their instruments appropriate to the character of loud - soft sounding. Have students be responsible to work in orchestration to the playing of the gamelan instruments.

\section{Procedure 3: 20 minutes}

Have students play the instruments based Ibu Pertiwi song. Have students pay attention to the drummer - Javanese pengendang who functions as audible conductor and the rebab player or the twostringed fiddle who shares to guide the orchestra especially when the gamelan composition in soft sections. Have students play the embellishing instruments of the bonang, suling, celempung and zither, gender, gambang, and peking which elaborate the skeletal melody.

Have the pesindhen or female singers sing in rhythmic and ornate elasticity throughout the piece. Have the gerongan or the male choruses choir as well as clap their hands to the accompaniment of the skeletal melody - Javanese balungan.

Note: To master the playing of gamelan instruments, students need to repeat a number of times.

\section{Procedure 4: 5 minutes}

Have students explain briefly and orally about their playing of the gamelan instruments.

\section{Day 2:}

\section{Procedure 5: 15 minutes}

Have students decide what weakness they need to work on the playing of instruments they choose. Have students be 
flexible to shift to the playing of any gamelan instruments to maximize both technical skills and aesthetic sensibilities.

\section{Procedure 6: 25 minutes}

Have students a careful warm-up before they perform in from of the audience.

Students are told to be relax physically and concentrate mentally during the performance.

Have students concentrate on the instruments they play and connect them to the rest of the melodic lines.

\section{Evaluation}

Teacher together with gamelan teacher apprentice students to play the gamelan instruments.

Teacher observes and monitors students' democratic behavior through the playing of the gamelan.

\section{Expectation and Adaptations}

Students can create cultural portfolio representing their culture.

Students can create cultural-box containing pictures of musical instruments.

\section{CONCLUSION}

This study offers a framework for gamelan music-social studies connections. Foremost, the study on gamelan has intertwined potentials for eliciting students' historical thinking skills and enhancing students' democratic habits of mind. While social studies educators would agree that teachers can use music to enhance democratic thinking, no one has systematically researched student interaction with gamelan musical forms to assess music's potential power for enhancing democratic values. This includes the Javanese value of collective decisionmaking, collaborative leadership, and cooperation. This research, with its unit plan and lessons, positions junior high school students to study gamelan's cooperative playing. By having subjects reflect upon gamelan playing, the research elicits discussions about democratic decision- making: individual expression and production of beauty through individual contributions to a collective production.

\section{Acknowledgement: None}

\section{Conflict of Interest: None}

\section{Source of Funding: None}

\section{REFERENCES}

1. Bakan, M. 2011. World music: Traditions and transformations. New York, NY; McGraw-Hill.

2. Beane, J.A. 1997. Curriculum integration: Designing the core of democratic Education. New York: Teachers College Press.

3. Bresler, L. 1995. The subservient, co-equal, affective, and social integration styles and their implications for the arts. Arts Education Policy Review, 96 (5), 31 - 37

4. Berke, M.K. 2000. Curriculum integration: A two-way street. General Music Today,(1), 9-12.

5. Burstein, J. H. \& Knotts, G. 2010. Creating connections: Integrating visual arts with social studies. Social Studies and Young Learners 23 (1): 2 - 23

6. Hood, M. 1980. The evolution of Javanese gamelan, Book I. Music of the roaring sea. Glendale, NY; C.F. Peters.

7. Isenberg, J. \& Jalongo, M. 2010. Creative thinking and Arts-based learning: Preschool through fourth grade. Upper Saddle River, NJ: Pearson Merril Prentice Hall

8. Kurt, S. 2021. Constructivist learning theory. In Educational technology. Retrieved from https://educationaltechnology.net/constructi vist-learning-theory/

9. Mardiati, Y., Wasino, Puguh, D.R., Handoyo, E. 2019. Incorporating Javanese gamelan music as democratic pedagogy: A junior high school social studies teacher's perspective. Retrieved on April 3, 2020, from https://eudl.eu/pdf/10.4108/eai.29-62019.2290364

10. Meleisea, E. 2005. Educating for creativity: Bringing the arts and culture into Asian education. Retrieved from http://files.eric.ed.gov/fulltext/ED496233.pd $\mathrm{f}$

11. Merriam. A. (1969). Ethnomusicology revisited. Ethnomusicology, 13, 213-229. 
12. National Council for the Social Studies: A Framework for Teaching, Learning, and Assessment. 2010. Retreived from https://socialstudies.org/standards

13. Özgül, I. 2016. Integration in general music education. Conference of the International Journal of Arts \& Sciences, 09 (02): 53-60

14. Parsons, M. 2004. Art and integrated curriculum. In E. W. Eisner \& M. D. Day (Eds.), Handbook of research and policy in art education (pp. 775-794). Mahwah, NJ: Lawrence Erlbaum.

15. Peraturan Menteri Pendidikan dan Kebudayaan No. 21 Tahun 2016 tentang Standar Isi Pendidikan Dasar dan Menengah. Retreived on April 7, 2020, from https://bnspindonesia.org/wp/content/uploads/2009/06/ Permendikbud_Tahun 2016_Nomor021.pdf

16. Peraturan Menteri Pendidikan dan Kebudayaan No. 22 Tahun 2016 tentang Standar Proses Pendidikan dasar dan Menengah. Retreived on April 7, 2020, from https://bnspindonesia.org/wp/content/uploads/2009/06/ Permendikbud_Tahun 2016_Nomor022.pdf

17. Silverstein, L., \& Layne, S. 2010. What is art integration? Chapter in Silverstein, L., Duma, A.L., and Layne, S. Arts integration schools: What, why, and how (Tap 2, pp. 17). Washington, DC: The John F. Kennedy Center for the Performing Arts/Changing
Education through the Arts (CETA) program.

18. Taylor, J. A., Mouck, T., \& Ayaub, S. 2014. Arts integration in social studies: Research from the field. The councilor: A Journal of the Social Studies, 75 (1), 23-48.

19. VanSledright, B. A. 2002. What does it mean to think historically and how do you teach it? Social education, 68 (3), 230-233

20. Werner, L., \& Freeman, C. j. 2001. Arts for academic achievement: Arts integration-A vehicle for changing teacher practice. Minneapolis, MN: Center for applied research and educational improvement, College of education and human development.

21. Zarillo, J. 2012. Teaching elementary social studies: Principles and applications, $4^{\text {th }}$ edition. Boston, MA: Allyn \& Bacon.

22. Zhou, M., \& Brown, D. 2018. Arts integration in elementary curriculum: $2^{\text {nd }}$ Edition. Education open textbooks 3. Retrieved on May 14, 2020, from https://oer.galileo.usg.edu/educationtextbooks/3

How to cite this article: Mardiati Y, Wasino, Puguh DR et.al. Making connection: integrating gamelan music into social studies classroom. International Journal of Research and Review. 2021; 8(7): 236-244. DOI: https://doi.org/10. 52403/ijrr.20210733 